\title{
Purine Nucleoside Phosphorylase Deficiency Associated with a Dysplastic Marrow Morphology
}

\author{
YIGAL DROR, EYAL GRUNEBAUM, JOHANN HITZLER, ARU NARENDRAN, CHARLES YE, \\ RAYMOND TELLIER, VERNON EDWARDS, MELVIN H. FREEDMAN, AND \\ CHAIM M. ROIFMAN
}

Division of Hematology and Oncology [Y.D., J.H., A.N., M.H.F.], Division of Immunology and Allergy [E.G., C.M.R.], Department of Pediatrics, Program of Infection Immunity Injury and Repair [E.G., R.T., M.H.F., C.M.R.], Program of Cancer and Blood, Research Institute [J.H.], Department of Pathology and Laboratory Medicine [C.Y., R.T.], The Hospital for Sick Children, University of Toronto, Toronto,

Ontario, M5G 1 X8, Canada

\begin{abstract}
ABST
Purine nucleoside phosphorylase (PNP) deficiency is an au-
tosomal recessive metabolic disorder characterized by severe
combined immunodeficiency and by complex neurologic symp-
tomatology including ataxia, developmental delay, and spastic-
ity. Herein we report severe marrow dysplasia in a patient with
PNP deficiency. Drug-related marrow dysfunction was unlikely,
and marrow virological studies were negative. A preleukemic
myelodysplastic syndrome was also unlikely due to normal
marrow CD34+ cells, colony growth in clonogenic assay of
marrow mononuclear cells, apoptosis rate, and Fas expression on
marrow nucleated cells, as well as morphologic improvement of
the marrow dysplasia after normal red blood cell transfusion. The
patient's marrow stroma showed hypersensitivity to irradiation
and undetectable PNP enzyme activity similar to peripheral
\end{abstract}
lymphocytes. This is the first report of PNP deficiency associated with increased lymphocyte and marrow stromal sensitivity to irradiation. We conclude that marrows from patients with PNP deficiency might have hypersensitivity to irradiation and can develop dysplastic morphology, caused either directly or indirectly by the inherited enzymatic defect. (Pediatr Res 55: 472477, 2004)

\[ \begin{array}{c}\text { Abbreviations } \\ \text { BFU-E, erythroid burst forming unit }\end{array} \]
CFU-GM, granulocytic monocytic colony forming unit
CFU-mix, mixed colony forming unit
PE, phycoerythrin
PNP, purine nucleoside phosphorylase

PNP deficiency results in severe combined immunodeficiency with profound T-cell abnormalities and variable B-cell function $(1,2)$. Patients with PNP deficiency suffer from recurrent bacterial, viral, and fungal infections of varying severity. Infections usually begin early in life, but may appear in late childhood (2). Other complications include spasticity, mental retardation, and autoimmune diseases. Without bone marrow transplantation, patients with PNP deficiency die from uncontrolled infections or malignancy during their first decade of life (1).

The PNP protein reversibly catalyzes the degradation of the purine nucleosides inosine and deoxyinosine to hypoxanthine and

Received February 3, 2003; accepted September 2, 2003.

Correspondence: Chaim M. Roifman, M.D., Division of Immunology and Allergy, The Hospital for Sick Children, 555 University Ave., Rm. 7279 Elm Wing, Toronto, Ontario, M5G 1X8, Canada; e-mail: chaim.roifman@sickkids.ca

Supported in part by grants from Donor Directed Fund to the Division of Hematology/ Oncology through the Hospital for Sick Children Foundation, the Canadian Institute of Health Research, and The Jeffrey Modell Foundation. C.M.R holds the Donald and Audrey Campbell Chair of Immunology.

Y.D. and E.G. contributed equally to this study.

DOI: 10.1203/01.PDR.0000111286.23110.F8 guanosine and deoxyguanosine to guanine $(3,4)$. PNP is highly expressed in lymphoid tissues (2). Abnormal PNP activity results in deoxyguanosine triphosphate accumulation in the mitochondria, which inhibits mitochondrial DNA repair. This leads to increased sensitivity of $\mathrm{T}$ lymphocytes to DNA damage and apoptosis during thymus selection (5). PNP is encoded by six exons spanning $9 \mathrm{~kb}$ of chromosome $14 \mathrm{q} 13(6,7)$. Relatively few mutations have been reported in PNP deficiency (8-14), with variable degrees of enzymatic activity, which might in part explain variability in disease course $(12,13,15-18)$.

Rare cases of megaloblastoid and dysplastic changes in marrow morphology were reported in PNP deficiency $(19,20)$, but these were not further investigated or characterized. Herein we describe for the first time a patient with PNP deficiency, who developed severe trilineage marrow dysplasia. The relationship between PNP deficiency and myelodysplasia is discussed.

\section{PATIENT}

The patient (male) was born to healthy parents of mixed Caucasian and Japanese origin. He had prolonged parvovirus 
infection with pure red cell aplasia at the age of 26 mo and varicella zoster infection at the age of $32 \mathrm{mo}$. The pure red cell aplasia resolved completely, but later on at the age of $35 \mathrm{mo}$ he suffered severe hemolytic anemia associated with mycoplasma pneumonia infection. He continued to experience intermittent mild to moderate autoimmune hemolytic episodes associated with the development of anti-C3d antibody. In addition, the patient had mild gross motor and speech developmental delay. On physical examination he had no palpable lymph nodes or tonsils, as well as mild ataxia.

The patient's immunologic and genetic studies have been previously reported (14). In brief, immunologic investigation revealed low lymphocyte count, low CD2 (46\%), CD3 (16\%), CD4 (13\%), CD8 (2\%), and abnormally reduced in vitro responses to the mitogens phytohemagglutinin, concavalin $\mathrm{A}$, staphylococcal-antigen Cowan strain I, and staphylococcal protein A. Lymphocyte adenosine deaminase enzyme activity was normal and PNP enzyme activity was undetectable. B-cell function and numbers as measured by immunoglobulin ( $\operatorname{IgA}$, $\mathrm{IgG}, \mathrm{IgM}$ ) levels, isohemagglutinins, specific antibody titers to tetanus toxoid, polioviruses 1,2 , and 3 , and lymphocyte subpopulations bearing CD19 and CD56 were all normal.

The patient had two novel mutations of the PNP gene. The maternal-derived allele carried a $\mathrm{C}$ to $\mathrm{T}$ transition in exon 2 resulting in a premature stop codon at amino acid 57. The paternal-derived mutation caused skipping of exon 3, as a result of a $\mathrm{G}$ to $\mathrm{A}$ transition at position +1 of intron 3 resulting in a reading frameshift and the predicted polypeptide termination at amino acid 89.

A donor for hematopoietic stem cell transplantation was not available. At the age of $8 \mathrm{y}$ the patient developed progressive anemia, erythrocytic macrocytosis, and neutropenia without preceding recent infections. At that time he had been receiving treatment with acyclovir, cotrimoxazole, alternate-day lowdose prednisone, and monthly immunoglobulins. At the age of 8 y and 3 mo he developed recurrent left popliteal deep vein thrombosis, which was treated with enoxaparin, and skin rash.

Laboratory investigation at this stage revealed $\mathrm{Hb} 89 \mathrm{~g} / \mathrm{L}$, mean corpuscular volume $114 \mathrm{fL}$, reticulocytes $59 \times 10^{9} / \mathrm{L}$, and platelets $286 \times 10^{9} / \mathrm{L}$. Total white blood cells gradually decreased to $1.6 \times 10^{9} / \mathrm{L}$ with neutrophils of $0.8 \times 10^{9} / \mathrm{L}$, with no blasts, lymphocytes $0.11 \times 10^{9} / \mathrm{L}$, monocytes $0.35 \times 10^{9} / \mathrm{L}$. His eosinophils, which were low at the stage of the leukopenia, gradually increased to $7.0 \times 10^{9} / \mathrm{L}$. Peripheral blood smear showed macrocytic red blood cells. The following tests were within normal limits: serum ferritin; serum B12; red blood cell folate; antineutrophil antibody; antiplatelet antibody; liver and renal function; TSH; antinuclear antibody; antineutrophil cytoplasmic antibody; Ham's test; antithrombin 3; antiphospholipid antibody; protein $\mathrm{C}$; protein $\mathrm{S}$; activated protein $\mathrm{C}$ resistance; antiphospholipids; anticardiolipin antibody; prothrombin mutation; factor $\mathrm{V}$ Leiden; blood cultures for bacteria, mycobacteria, and fungi; serology for trichinella, toxocara, and mycoplasma; and chest x-ray. Abdominal ultrasound showed mild splenomegaly and a few periportal nodes. Computed tomography of the brain revealed an old infarct in the left caudate nucleus with mild generalized atrophy. Total body gallium scan and echocardiogram were normal.
Bone marrow biopsy and aspirate showed a normocellular specimen with prominent trilineage dysplasia including multinucleated erythroid precursors, granulocytes with bizarre or hypersegmented nuclei, and micromegakaryocytes (Fig. 1, $A-D)$. Immunostaining with an anti-factor VIII antibody showed dysplastic unilobulated megakaryocytes (Fig. 1E). Eosinophilic hyperplasia with numerous precursors and mature forms were also present. No ring sideroblasts were found on Prussian blue stain. There was no fibrosis or abnormal localization of immature precursors on the biopsy specimen. Marrow cell differential at this stage showed myeloblasts $4 \%$, promyelocytes $5 \%$, myelocytes $14 \%$, metamyelocytes $6 \%$, bands $6 \%$, polymorphonuclear $7 \%$, erythroblasts $42 \%$, eosinophils $12 \%$, lymphocytes $5 \%$. No characteristic findings of parvovirus B19 infection were found at this stage; specifically, there were no signs of pure red cell aplasia and bizarre giant proerythroblasts. Further, PCR of genomic DNA extracted from marrow cells was negative for parvovirus B-19. We used the primers 5' (AGT AAA GAA AGT GGC AAA TGG) 3' and 5' (TAC TAC TTG TGC TTG AAA CCC) $3<$ prime >, which target a region of the VP1 gene highly conserved across all genotypes of parvovirus B-19. The expected size of the amplicon is $576 \mathrm{bp}$, and its identity is verified by digestion with the restriction enzyme ApaI. PCR was also negative for human herpes virus 1, 2, 6, 7, and 8; Epstein-Barr virus; cytomegalovirus; and varicella zoster virus. In situ hybridization for EBV and cytomegalovirus were negative. Cytogenetic analysis of marrow cells showed 46,XY.

Discontinuation of cotrimoxazole and acyclovir did not improve the cytopenia or the bone marrow morphology. Due to progressive anemia the patient received red blood cell transfusions. Interestingly, $1 \mathrm{wk}$ after red blood cell transfusion (which of course contain PNP) the marrow abnormalities dramatically improved, and only few dysplastic erythroblasts and megakaryocytes could be seen. Marrow cell differential at this stage showed myeloblasts $4 \%$, promyelocytes $4 \%$, myelocytes $25 \%$, metamyelocytes $12 \%$, bands $11 \%$, polymorphonuclear $10 \%$, erythroblasts $24 \%$, eosinophils $8 \%$, and lymphocytes $2 \%$. A month later, during a prolonged illness with herpes zoster, and while on therapeutic blood enoxaparin levels, he developed frontal intracranial hemorrhage and died with progressive cerebral edema and neurologic deterioration despite medical and neurosurgical interventions.

\section{MATERIAL AND METHODS}

Electron microscopy. A portion of this bone marrow biopsy was fixed in universal fixative (equal parts of $1 \%$ glutaraldehyde and $4 \%$ formaldehyde) and postfixed in $1 \%$ osmium tetroxide, dehydrated in graded alcohols and propylene oxide, and embedded in Epon. One-micrometer-thick sections were stained with toluidine blue. Ultrathin sections were stained with uranyl acetate and lead citrate, and examined under a JEOL 1230 transmission electron microscope (JEOL, Tokyo, Japan).

Percentage of CD34+ cells in marrow cell samples. Bone marrow aspirates collected in preservative-free heparin underwent Ficoll (Amersham Pharmacia Biotech AB, Uppsala, Swe- 

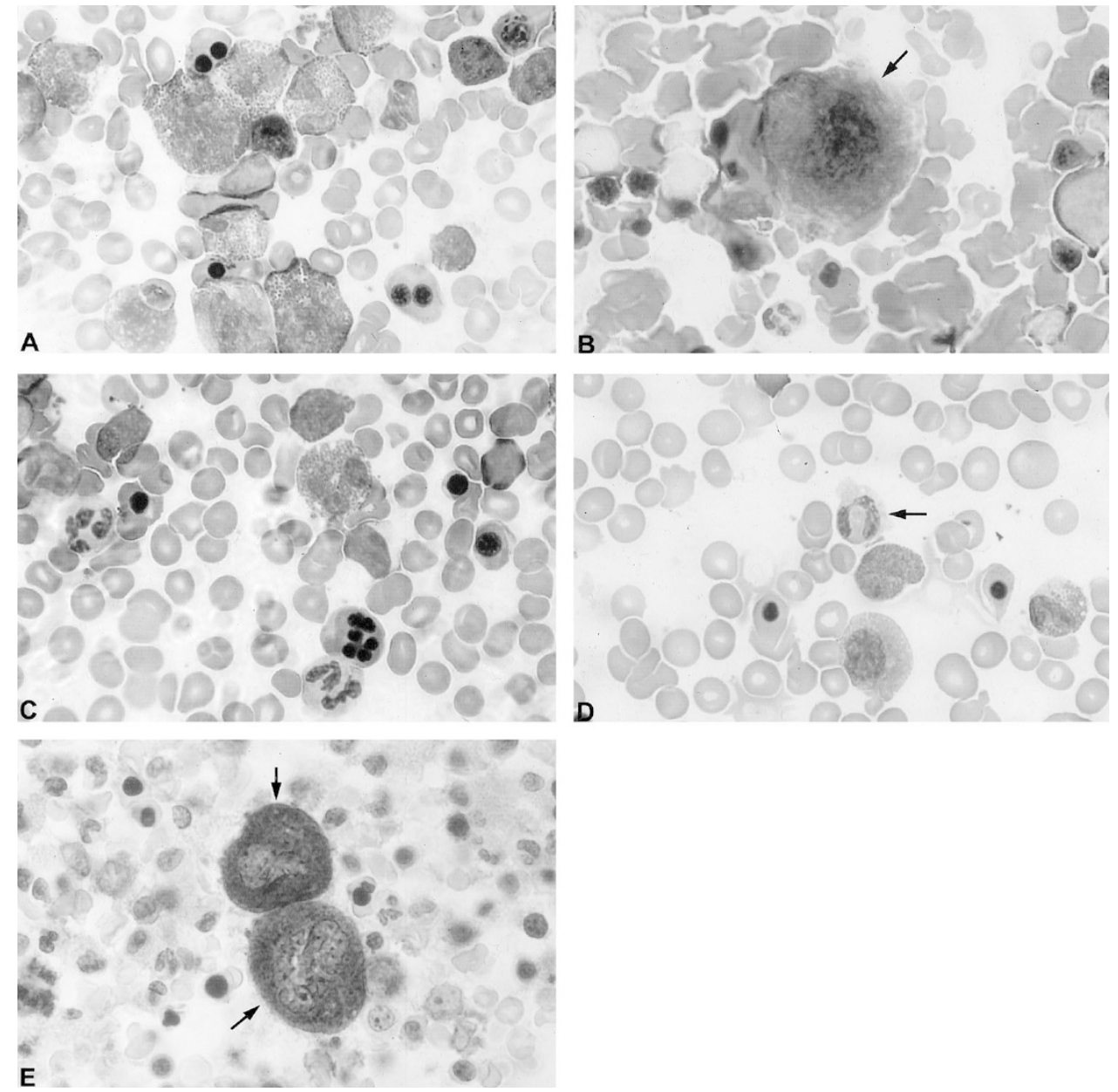

Figure 1. Bone marrow morphology. Bone marrow aspirate of the patient at age 8 y showing prominent trilineage dysplasia, including multinucleated erythroid precursors $(A)$, micromegakaryocytes $(B)$, and granulocytes with bizarre nuclei $(C, D)$. Immunostaining with an anti-factor VIII antibody showed dysplastic unilobulated megakaryocytes $(E)$.

den) fractionation. Cells $\left(1 \times 10^{5}\right)$ were incubated as previously described (21) with either FITC-conjugated anti-CD34+ antibody or IgG1-FITC isotype control (both from Immunex, Seattle, WA, U.S.A.), resuspended in PBS with paraformaldehyde $0.5 \%$, and immediately analyzed by a Coulter Epics XL-MCL flow cytometer (Beckman Coulter, Inc., Fullerton, CA, U.S.A.). At least 12,000 events were collected.

Clonogenic assays of marrow mononuclear cells. Percolled marrow cells (21) were plated in duplicate at a density of $2 \times$ $10^{5}$ marrow mononuclear cells $/ 1 \mathrm{~mL}$ dish containing $40 \mathrm{U} / \mathrm{mL}$ IL-3 (Immunex), $10 \mathrm{ng} / \mathrm{mL}$ granulocyte-colony stimulating factor (Amgen Biologicals, Thousand Oaks, CA, U.S.A.), 50 $\mathrm{ng} / \mathrm{mL}$ mast cell growth factor (Immunex), and $2 \mathrm{U} / \mathrm{mL}$ erythropoietin (Ortho Biologics, Manati, Puerto Rico) as well as methylcellulose and FCS. Cultures were incubated and scored after $14 \mathrm{~d}$ under an inverted microscope for formation of clusters $(20-50$ cells) or colonies ( $>50$ cells): CFU-GM, BFU-E, or CFU-mix.

Apoptotic rates of hematopoietic cells. Post-Ficoll bone marrow light density cell fraction $\left(1 \times 10^{6}\right.$ cells $\left./ \mathrm{mL}\right)$ from the patient and normal controls were plated in cultures containing RPMI with $15 \%$ FCS for $24 \mathrm{~h}$. Nonadherent cells were then harvested. To a $1 \times 10^{5}$ washed cell mixture, FITC-conjugated annexin V (10 $\mu \mathrm{L}, \mathrm{R} \&$ D Systems, Minneapolis, MN, U.S.A.) and propidium iodide ( $10 \mu \mathrm{L}, \mathrm{R} \& \mathrm{D}$ Systems) were added, and cells were incubated in the dark for $15 \mathrm{~min}$ at room temperature (22). Subsequently, binding buffer (R \& D Systems) was added, and cells were immediately analyzed by Coulter Epics XL-MCL flow cytometer (Beckman Coulter). Events falling outside the negative staining regions identified by the control samples were considered positive staining for either annexin $\mathrm{V}$ only (early apoptosis) or annexin $\mathrm{V}$ and propidium iodide (late apoptosis/necrotic cells).

Fas expression on marrow cells. Post-Ficoll bone marrow light density cells $\left(1 \times 10^{5}\right)$ were incubated with either PEconjugated mouse anti-human Fas IgM MAb (clone 7C11, 8 $\mu \mathrm{L} / 10^{5}$ cells) or PE-conjugated IgM mouse isotype control (clone GC323, $8 \mu \mathrm{L} / 10^{5}$ cells) (both purchased from Immunotech, Marseille, France). Cells were incubated with the antibody in the dark at $4^{\circ} \mathrm{C}$ for $30 \mathrm{~min}$, washed twice, and analyzed by flow cytometry. A minimum of 10,000 events was collected.

Sensitivity to irradiation. Sensitivity of peripheral blood lymphocytes to irradiation was evaluated using $\mathrm{T}$ lymphocytes purified from the patient's and normal control's peripheral blood by Ficoll separation and B-cell rosetting. T cells $(1 \times$ 
$10^{6} / \mathrm{mL}$ ) were exposed to varying doses of gamma irradiation. The cells were then cultured in 96 flat-bottomed plates in the presence of phytohemagglutinin $(5 \mu \mathrm{g} / \mathrm{mL})$ and IL-2 (10 $\mathrm{U} / \mathrm{mL}$ ). Lymphocyte proliferation was measured after $72 \mathrm{~h}$. Eight hours before the termination of the culture, $1 \mu \mathrm{Ci}$ $\left[{ }^{3} \mathrm{H}\right]$ thymidine was added. All experiments were done in triplicates.

Sensitivity of marrow stromal cells was evaluated using stromal cell layers established as previously published (21) with few modifications. Briefly, post-Ficoll marrow mononuclear cells were cultured overnight at approximately $2 \times 10^{6}$ cells/flask (Falcon, $75 \mathrm{~cm}^{2}$ ) in OPTI-MEM (Invitrogen, Carlsbad, CA, U.S.A.) containing 5\% FCS (Invitrogen). Nonadherent cells were removed by gentle washing with culture medium and adherent cells were cultured for an additional $6 \mathrm{~d}$. Cells were then removed by mild trypsinization $(0.05 \%$ trypsin in EDTA, Invitrogen), replated in the same medium, and allowed to grow to approximately $60 \%$ confluency. Cells used in this study were obtained after approximately four such cycles, and microscopic examination showed no hematopoietic cells or leukemic cells.

Exponentially growing stromal cells were trypsinized, washed, resuspended in OPTI-MED containing 5\% FCS (Invitrogen), and plated at a density of $10^{5}$ cells/35-mm dish. After overnight incubation, the cells were irradiated at various doses. After an additional $4 \mathrm{~d}$ in culture, the number of viable cells were quantitated using an MTT [3-(4.5-dimethylthiazol2-yl)-2.5-diphenyltetrazolium bromide] based colorimetric assay as described by the manufacturer (Sigma Chemical, St. Louis, MO, U.S.A.).

PNP activity of the marrow stroma. PNP enzymatic activity in the marrow stroma of the patient and normal controls was assessed in cell lysates using cellulose TLC with $\left[8^{-14} \mathrm{C}\right] \mathrm{i}-$ nosine $(50 \mathrm{mCi} / \mathrm{mmol}$; Moravek Biochemicals, Brea, CA, U.S.A.) as substrate, as described previously (23).

\section{RESULTS}

Electron microscopy. Ultrastructural evaluation of the erythroblasts shows vacuolization of the nuclear heterochro- matin to give an overall spongy "Swiss cheese" appearance, enlargement of the nuclear pores with partial loss of the nuclear envelope, invaginations of cytoplasmic portions into the nuclei of the erythroblasts through the absent areas of the nuclear envelope, and the presence of cytoplasmic myelin-like figures (Fig. 2). These findings are comparable with those seen in congenital dyserythropoietic anemia type I. There were also pluripolar mitoses, karyorrhexis, and formation of cytoplasmic marginal cisternae as seen in congenital dyserythropoietic anemia type II. Giant multinucleated erythroblasts, nuclear clefts and blebs, and the presence of iron-filled mitochondria as seen in congenital dyserythropoietic anemia type III were not observed.

Percentage of CD34+ cells in marrow cell samples and clonogenic assays of marrow mononuclear cells. Patients with preleukemic myelodysplastic syndrome may have high percentage of marrow $\mathrm{CD} 34+$, which correlates with advanced disease stage. Flow cytometric analysis of post-Ficolled marrow samples using a FITC-conjugated anti-CD34+ antibody showed 5\% CD34+ cells in the patient's marrow, which was comparable to the percentage from 10 normal controls (mean \pm SD: $4.4 \% \pm 1.7 \%$ ).

Clonogenic potential of patients' marrow mononuclear cells was normal: means of duplicate CFU-GM, BFU-E, and CFUmix colonies were 288,67 , and 4 , respectively. Means of controls' marrow were $70-300,50-180$, and $2-15$, respectively. Also, the ratio of cluster-to-colony formation was normal at 0.09 (means of controls: 0.10; range, 0.03-0.18), which is consistent with early, rather than advanced, myelodysplastic syndrome.

Apoptotic rates of hematopoietic progenitor cells and Fas expression. Apoptosis rate of marrow cells was determined by flow cytometry after staining post-Ficoll samples with annexin $\mathrm{V}$ and propidium iodide. Apoptotic cells were identified as annexin V-positive, propidium iodide-negative events. Patient's marrow cells showed apoptosis rate of $13 \%$, which was comparable to normal controls (mean $\pm \mathrm{SD}, 17 \% \pm 8 \%, n=$ 10).

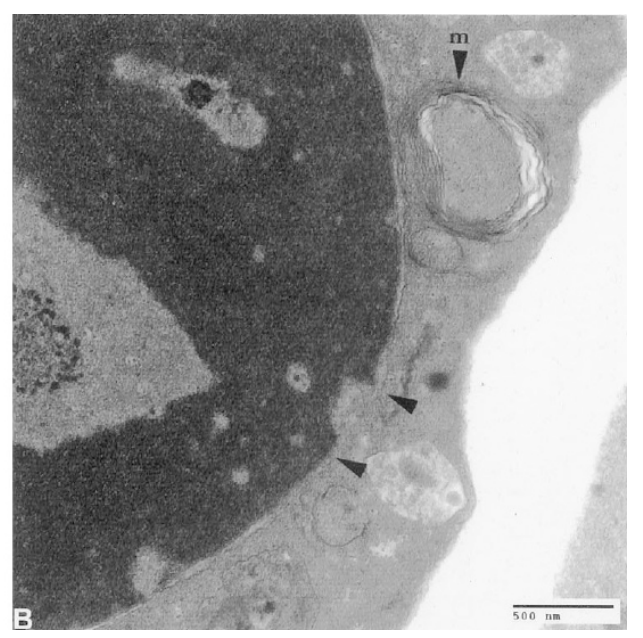

Figure 2. Electron microscopy of patient bone marrow. (A) High-power view of a binucleated erythroblast to show the chromatin transformation to a "Swiss cheese" appearance (asterisks). Note cytoplasmic invagination into the nucleus (c). Lead citrate and uranyl acetate stain. Bar: $500 \mathrm{~nm}$. (B) Higher-power view to show the loss of the nuclear membrane (arrowheads) and the presence of a myelin figure $(m)$. Lead citrate and uranyl acetate stain. Bar: $500 \mathrm{~nm}$. 
Flow cytometric analysis of post-Ficoll marrow samples using a PE-conjugated anti-Fas antibody showed 3\% Fas + cells in the patient's marrow, which was in the normal range (mean $\pm \mathrm{SD}, 17 \% \pm 10 \%, n=10$ ).

Sensitivity to gamma irradiation. The sensitivity of peripheral T lymphocytes from the PNP-deficient patient and normal controls to gamma irradiation and their proliferation was investigated after stimulation by phytohemagglutinin. Exogenous IL-2 was added to all cultures, as PNP-deficient T cells have decreased mitogenic responses in the absence of IL-2 (15). Similar to PNP-deficient bone marrow stroma cells, peripheral $\mathrm{T}$ lymphocytes from the patient were more sensitive to gamma irradiation $(90 \%$ reduction at $500 \mathrm{cG})$ than those from a normal control $(970 \mathrm{cG})$. Results are representative of three experiments.

To assess the sensitivity of bone marrow stroma to gamma irradiation, marrow stromal layers from the PNP-deficient patient and normal controls were established. After four cycles of subculturing, stromal layers were gamma irradiated at various doses, and assayed by MTT-based colorimetric method. Marrow from PNP-deficient patient was more sensitive to gamma irradiation $(66 \%$ reduction at $500 \mathrm{cG}$ ) than normal bone marrow stroma cells ( $0 \%$ reduction at $500 \mathrm{cG})$ (Fig. 3).

PNP enzyme activity. To confirm that the above stromal cell defect is indeed related to the patient's genetic defect, PNP enzymatic activity in the marrow stroma of the patient and normal controls was assessed. Similar to absent PNP enzyme activity in peripheral lymphocytes (data not shown), PNP enzymatic activity in the bone marrow stroma cell derived from the PNP-deficient patient was undetectable, in contrast to bone marrow derived from normal controls.

\section{DISCUSSION}

The present case demonstrated severe trilineage morphologic dysplasia of marrow cells in a patient with PNP deficiency. Dyserythropoiesis was particularly marked, and electron microscopic examination showed dysplastic changes in the erythroid lineage comparable in severity to those observed in congenital dyserythropoietic anemia. After developing mar-

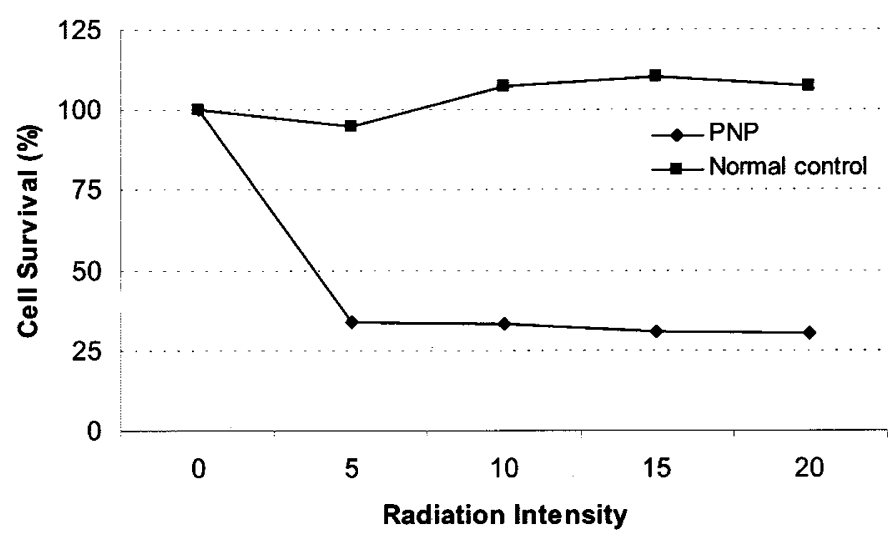

Figure 3. Sensitivity of patient stromal cells to gamma radiation. Cell viability of marrow stromal cells from the patient and a normal control determined by the MTT method in response to various doses of gamma irradiation. row dysfunction the patient course was characterized by successive complications, including deep venous thrombosis, prolonged herpes zoster infection, and fatal intracranial hemorrhage.

A major question in the present case is whether the marrow dysfunction is directly related to the inherited genetic background, namely PNP deficiency and accumulation of toxic purine metabolites, or to an acquired factor. Indeed, purine metabolites were reported to be associated with dysplastic marrow morphology. For example Orchard et al. (24) found frequent marrow dysplasia in patients treated with the purine analogue, fludarabine. They speculated that a number of key enzymes, including DNA polymerase alpha, DNA primase, DNA ligase, and ribonucleotide reductase, might be impaired, thus contributing to the dysplastic changes. Further, cases of PNP deficiency associated with megaloblastic and dysplastic marrows have previously been reported $(19,20)$. All the above support the notion that the severe marrow changes in the present case might be directly caused by the accumulation of deoxyguanosine and other metabolites in PNP deficiency. If this was the mechanism of the marrow dysplasia in our patient, then providing exogenous PNP should improve or reverse the process (25). Indeed, repeat transfusion of red blood cells improved marrow morphology in our patient.

Marrow-directed autoimmunity is occasionally seen in systemic autoimmune disorders (26-33). However, no evidence for autoantibody production could be demonstrated in the present case. As previously mentioned, drug- and viral-induced dysplasia are also unlikely to play a role in the pathophysiology of the disorder in the present case. Specifically, although the patient had parvovirus infection at the age of $26 \mathrm{mo}$, this resolved completely, and at the stage of the marrow dysplasia (8 y of age), PCR of genomic DNA from marrow cells using specific primers for the parvovirus VP1 gene was negative. Although childhood myelodysplastic syndromes are frequently associated with an underlying genetic predisposition (34), it is unlikely that the patient developed true premalignant myelodysplastic syndrome. High frequencies of neoplastic diseases have been described in PNP deficiency $(2,35)$, but these are usually lymphoid and not myeloid. Further, the normal marrow cellularity, colony growth, cluster-to-colony ratio, marrow cell apoptosis rates, marrow cell Fas expression, and the improvement in marrow morphology after red cell transfusion are all uncharacteristic of a preleukemic myelodysplastic syndrome.

Increased sensitivity of PNP-deficient thymocytes to gamma-irradiation has been described in animal models (5). We demonstrate for the first time that peripheral $\mathrm{T}$ lymphocytes from a patient with PNP are also highly sensitive to irradiation. This can be related to imbalance of dNTP that has been shown to interfere with DNA repair. Environmental factors including radiotherapy are known to induce DNA damage and myelodysplasia (36). Thus, radiosensitivity, which is a feature of certain syndromes with a predisposition to myelodysplastic syndromes (e.g. Fanconi's anemia and Bloom's syndrome), might be a contributory factor in the development of the dysplasia in this patient.

Radiosensitivity of lymphocytes has been described in several immunodeficiencies such as ataxia telangiectasia, Nijme- 
gen breakage syndrome, and adenosine deaminase deficiency (37). The decreased stromal cell viability in response to irradiation is consistent with the previous findings in PNPdeficient thymocytes (5). Marrow stromal abnormalities were described in de novo myelodysplastic syndrome and in Shwachman-Diamond syndrome, a preleukemic inherited marrow failure syndrome (21). Further studies are necessary to determine the relationship between the marrow stromal defect and the morphologic dysplasia and cytopenia.

Acknowledgment. The authors thank Wilma Vanek for technical assistance.

\section{REFERENCES}

1. Giblett ER, Ammann AJ, Sandman R, Wara DW, Diamond LK 1975 Nucleosidephosphorylase deficiency in a child with severely defective T-cell immunity and normal B-cell immunity. Lancet 1:1010-1013

2. Markert ML 1993 Purine nucleoside phosphorylase deficiency. In: Seligmann M Rosen FS (ed) Immunodeficiencies. Taylor \& Francis Inc, London, UK, pp 197-224

3. Zannis V, Doyle D, Martin Jr DW 1978 Purification and characterization of human erythrocyte purine nucleoside phosphorylase and its subunits. J Biol Chem 253:504510

4. Parks Jr RE, Agarwal RP 1972 Purine nucleoside phosphorylase. In: Boyer PD (ed) The Enzymes, 3rd Ed, Vol VII . Academic Press, New York, pp 483-514

5. Arpaia E, Gu Y, Dalal I, Kelly S, Hershfield M, Roifman CM, Cohen A 2000 Biochemical and immunological abnormalities in purine nucleoside phosphorylase deficient mice. Adv Exp Med Biol 486:41-45

6. Williams SR, Goddard JM, Martin Jr DW 1984 Human purine nucleoside phosphorylase cDNA and genomic clone characterization. Nucleic Acids Res 12:5779-5787

7. Ricciuti F, Ruddle FH 1973 Assignment of nucleoside phosphorylase to D-14 and localization of X-linked loci in man by somatic cell genetics. Nature 241:180-182

8. Williams SR, Gekeler V, McIvor RS, Martin Jr DW 1987 A human purine nucleoside phosphorylase deficiency caused by a single base change. J Biol Chem 262:23322338

9. Andrews LG, Markert ML 1992 Exon skipping in purine nucleoside phosphorylase mRNA processing leading to severe immunodeficiency. J Biol Chem 267:7834-7838

10. Aust MR, Andrews LG, Barrett MJ, Norby-Slycord CJ, Markert ML 1992 Molecular analysis of mutations in a patient with purine nucleoside phosphorylase deficiency. Am J Hum Genet 51:763-772

11. Pannicke U, Tuchschmid P, Friedrich W, Bartram CR, Schwarz K 1996 Two novel missense and frameshift mutations in exon 5 and 6 of the purine nucleoside phosphorylase (PNP) gene in a severe combined immunodeficiency (SCID) patient. Hum Genet 98:706-709

12. Markert ML, Finkel BD, McLaughlin TM, Watson TJ, Collard HR, McMahon CP, Andrews LG, Barrett MJ, Ward FE 1997 Mutations in purine nucleoside phosphorylase deficiency. Hum Mutat 9:118-121

13. Sasaki Y, Iseki M, Yamaguchi S, Kurosawa Y, Yamamoto T, Moriwaki Y, Kenri T, Sasaki T, Yamashita R 1998 Direct evidence of autosomal recessive inheritance or Arg24 to termination condon in purine nucleoside phosphorylase gene in a family with severe combined immunodeficiency patient. Hum Genet 103:81-85

14. Dalal I, Grunebaum E, Cohen A, Roifman CM 2001 Two novel mutations in a purine nucleoside phosphorylase (PNP)-deficient patient. Clin Genet 59:430-437
15. Cohen A, Grunebaum E, Arpaia E, Roifman CM 2000 Immunodeficiency caused by purine nucleoside phosphorylase deficiency. Immunol Allergy Clin North Am 20:143-159

16. Osborne WR, Scott CR 1980 Purine nucleoside phosphorylase deficiency: measurement of variant protein in four families with enzyme-deficient members by an enzyme-linked immunosorbent assay. Am J Hum Genet 32:927-933

17. Snyder FF 1991 Genetic model of purine nucleoside phosphorylase deficiency in the mouse. Adv Exp Med Biol 309B:137-140

18. Gelfand EW, Dosch HM, Biggar WD, Fox IH 1978 Partial purine nucleoside phosphorylase deficiency: studies of lymphocyte function. J Clin Invest 61:10711080

19. Carpenter PA, Xiegler JB, Vowels MR 1996 Late diagnosis and correction of purine nucleoside phosphorylase deficiency with allogenic bone marrow transplantation. Bone Marrow Transplant 17:121-124

20. Soutar RL, Day RE 1991 Equilibrium/ataxic diplegia with immunodeficiency. Arch Dis Child 66:982-983

21. Dror Y, Freedman MH 1999 Shwachman-Diamond syndrome: an inherited preleukemic bone marrow failure disorder with aberrant hematopoietic progenitors and faulty microenvironment. Blood 94:3048-3054

22. Dror Y, Freedman, MH 2001 Shwachman-Diamond syndrome marrow cells show abnormally increased apoptosis mediated through the Fas pathway. Blood 97:30113016

23. Cohen A, Gudas LJ, Ammann AJ, Staal GE, Martin DJ 1978 Deoxyguanosine triphosphate as a possible toxic metabolite in the immunodeficiency associated with purine nucleoside phosphorylase deficiency. J Clin Invest 61:1405-1409

24. Orchard, JA Bolam S, Oscier DG 1998 Association of myelodysplastic changes with purine analogues. Br J Haematol 100:677-679

25. Markert M, Hershfield MS, Schiff RI, Buckley RH 1987 Adenosine deaminase and purine nucleoside phosphorylase deficiencies: evaluation of therapeutic interventions in eight patients. J Clin Immunol 7:389-399

26. Della Rossa A, Tavoni A, Tognetti A, Testi C, Bombardieri S 1998 Behcet's disease with gastrointestinal involvement associated with myelodysplasia in a patient with congenital panhypopituitarism. Clin Rheumatol 17:515-517

27. Nam EJ, Kang YM, Kang HR, Kim JH, Rho HJ, Lee MK, Hyun SH, Kim GW, Lee JM, Kim NS 1999 Rheumatoid arthritis associated with myelodysplastic syndrome: a case report. J Korean Med Sci 14:319-322

28. Jimenez-Balderas FJ, Morales-Polanco MR, Gutierrez L 1994 Acute sideroblastic anemia in active systemic lupus erythematosus. Lupus 3:157-159

29. Lopez FF, Vaidyan PB, Mega AE, Schiffman FJ 2001 Aortitis as a manifestation of myelodysplastic syndrome. J Postgrad Med 77:116-118

30. Maeda Y, Arakawa K, Araki E, Kikuchi H, Ikezoe K, Taniwaki T, Kira J 1999 Polymyositis and cutaneous vasculitis in a patient with myelodysplastic syndrome. Rinsho Shinkeigaku 39:639-642

31. Farrell AM, Ross JS, Bunker CB 1999 Eosinophilic fasciitis associated with autoimmune thyroid disease and myelodysplasia treated with pulsed methylprednisolone and antihistamines. Br J Dermatol 140:1185-1187

32. Enright H, Miller W 1997 Autoimmune phenomena in patients with myelodysplastic syndromes. Leuk Lymphoma 24:483-489

33. Castro M, Conn DL, Su WP, Garton JP 1991 Rheumatic manifestations in myelodysplastic syndromes. J Rheumatol 18:721-727

34. Mandel K, Dror Y, Poon A, Freedman MH 2002 A practical comprehensive classification for pediatric myelodysplastic syndromes: the CCC system. J Pediatr Hematol Oncol 24:596-605

35. Soutar RL, Day RE 1991 Dysequilibrium/ataxic diplegia with immunodeficiency. Arch Dis Child 66:982-983

36. Krishnan A, Bhatia S, Slovak ML, Arber DA, Niland JC, Nademanee A, Fung H, Bhatia R, Kashyap A, Molina A, O’Donnel MR, Parker PA, Sniecinsk I, Snyder DS, Spielberger R, Stein A, Forman SJ 2000 Predictors of therapy-related leukemia and myelodysplasia following autologous transplantation for lymphoma: an assessment of risk factors. Blood 95:1588-1593

37. Regueiro JR, Porras O, Lavin M, Gatti RA 2000 Ataxia telangiectasia-a primary immunodeficiency revisited. Immunol Allergy Clin North Am 20:177-206 